\title{
Cave Microbes as a Potential Source of Drugs Development in the Modern Era
}

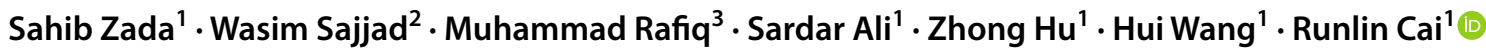

Received: 20 July 2021 / Accepted: 29 September 2021 / Published online: 25 October 2021

(c) The Author(s), under exclusive licence to Springer Science+Business Media, LLC, part of Springer Nature 2021, corrected publication 2021

\begin{abstract}
The world is constantly facing threats, including the emergence of new pathogens and antibiotic resistance among extant pathogens, which is a matter of concern. Therefore, the need for natural and effective sources of drugs is inevitable. The ancient and pristine ecosystems of caves contain a unique microbial world and could provide a possible source of antimicrobial metabolites. The association between humans and caves is as old as human history itself. Historically, cave environments have been used to treat patients with respiratory tract infections, which is referred to as speleotherapy. Today, the pristine environment of caves that comprise a poorly explored microbial world is a potential source of antimicrobial and anticancer drugs. Oligotrophic conditions in caves enhance the competition among microbial communities, and unique antimicrobial agents may be used in this competition. This review suggests that the world needs a novel and effective source of drug discovery. Therefore, being the emerging spot of modern human civilization, caves could play a crucial role in the current medical crisis, and cave microorganisms may have the potential to produce novel antimicrobial and anticancer drugs.
\end{abstract}

Keywords Cave ecosystem $\cdot$ Antibiotic resistance $\cdot$ Antimicrobial drugs $\cdot$ Speleotherapy

\section{Introduction}

Globalization and amplified movement, mainly air travel, have increased the ease of disease transmission locally and among continents. The recent Zika virus outbreak in the United States of America (USA), for instance, has been ascribed to the upsurge in air travel from infected areas to Brazil airports, spreading both the incidence and

Sahib Zada and Wasim Sajjad contributed equally to this work as the first authors

Runlin Cai

rlcai@stu.edu.cn

1 Biology Department, College of Science, Guangdong Provincial Key Laboratory of Marine Biotechnology, Institute of Marine Sciences, Shantou University, Shantou, China

2 State Key Laboratory of Cryospheric Science, Northwest Institute of Eco-Environment and Resources, Chinese Academy of Sciences, Lanzhou 730000, China

3 Department of Microbiology, Faculty of Life Sciences and Informatics, Balochistan University of IT, Engineering and Management Sciences, QUETTA, Pakistan geographic range of the virus. There is still no treatment for Zika virus infection or its associated diseases [1]. In 2003 , the outbreak of severe acute respiratory syndrome (SARS) in more than 20 countries and the recurrent Ebola outbreak in Central Africa showed that a new and existing disease could quickly become a substantial international health crisis [2]. Similarly, the Middle East respiratory syndrome coronavirus (MERS-CoV) has been reported in dromedaries in many countries of the Middle East, Africa, and South Asia. As a whole, 27 countries in the Middle East, Europe, North Africa, America, and Asia have reported MERS-CoV cases since 2012, causing 858 deaths [3]. Between 2012 and 30 June 2018, 2229 laboratoryconfirmed cases of MERS-CoV infection were reported, with $83 \%$ of the cases occurring in the Kingdom of Saudi Arabia [4].

Similarly, the ongoing coronavirus disease 2019 (COVID19) pandemic has been likened to a bulldozer, capable of causing widespread severe illness and deaths with terrifying speed and affecting individuals without discrimination [5]. Although some drugs and vaccines, including Pfizer, Moderna, Sinopharm, and Sinovac, have been introduced or are under investigation, there is no definite treatment 
for COVID-19. In short, there is no standard treatment for COVID-19 infection, and supportive treatment is the only strategy. The emergence of new pathogens have caused epidemics and global pandemics at different times (for example, the Nipah virus in Malaysia in 1998 [6], Plague in Algeria and Libya in 2003 and 2009 [7], H1N1/09 virus global pandemic in 2009 [8], MERS-CoV in 2009 [9], Zika virus 2015 in the Americas [10], and SARS-CoV-2 2019 global pandemic [9]) and posed major threats to public health, the economy, tourism, and trade. At present, COVID-19 has infected 216.2 million people with a total mortality of 4.499 million (28 August 2021. https://www.worldometers. info/coronavirus/). This has greatly negatively affected the world's public health, economy, tourism, trading, and other aspects. Nonetheless, drug development is a key strategy to prevent epidemics of infectious diseases, in order to reduce morbidity and mortality. Most of the typical options that guide drug manufacturing require years of development and are inadequate to deal with the ongoing outbreak. Therefore, in the modern world, it is crucial to explore natural and more effective sources of drugs.

Another aspect of the public health crisis is microbial resistance to antibiotics. Antibiotic resistance occurs when microbes alter their response to drugs and adopt strategies to defeat drugs. Although antibiotic resistance is a natural phenomenon, the misuse and overuse of antibiotics could accelerate this process. It is estimated that 34.8 billion doses of antibiotics have been used by humans every year, and the global consumption grew by $65 \%$ from 2000 to 2015 [11]. In the United Kingdom alone, nearly $20 \%$ of antibiotics were unnecessarily prescribed. Similarly, in the USA, this number increased by 33\% [12]. The World Health Organization (WHO) has reported that $17 \%$ of the falsified or substandard medicines are antibiotics, which further leads to drug resistance [4]. Current antibiotics mainly target the important functions of bacteria, including the synthesis of proteins, nucleic acids, cell walls, plasma membranes, and metabolic pathways. Nonetheless, bacteria can develop antibiotic resistance by mutating targets, pumping drugs out, or deactivating antibiotics [13]. According to the WHO, antibiotic resistance is one of the top ten threats to human public health. It has been estimated that by 2050 , infections due to antibiotic resistance may cause 10 million infections every year and could impose a burden of 100 trillion dollar to the world economy [14]. The number of antibiotic-resistant bacteria strains is increasing, but very few new antibiotics are being developed. Therefore, there is an urgent need for novel antibiotics in the near future to prevent public health crises.

The history of antibiotic development indicates a race between innovation and resistance. The time frame of the emergence and development of clinical drug resistance depends on several factors, including the dosage of antibiotics, the recommended frequency, the subtherapeutic amount of antibiotics used against resistant microorganisms, the origin of the existing resistance mechanisms, and the mutation numbers $[15,16]$. Microbial resistance to each major class of natural and synthetic antibiotics has developed from 1 to 10 years [17] after first approval for clinical use. Therefore, resistance is not a matter of "if," but a matter of "when." Once a novel antibiotic is approved for substantial clinical use, its lifetime begins to count down and resistant microbes emerge [18]. Once antibiotic-resistant germs cause infection, treatment becomes more difficult or even impossible. Sometimes, infections caused by antibiotic-resistant bacteria require prolonged hospitalization, further follow-up of doctor visits, costly and toxic alternatives, and more preventable deaths. Due to the use of antimicrobial agents in the medical sector, several aspects of antimicrobial resistance have been published. Many reports refer to the development of microbes resistant to different antibiotics, the rate of antibiotic resistance, and study the minimum inhibitory concentration (MIC) of different drugs [19]. Antibiotics used clinically have a limited shelf life, which is selected for bacteria with intrinsic or acquired resistance mechanisms. However, such bacteria are not common (e.g., 1 in $10^{8}$ ), and in the presence of particular antibiotics, drug-resistant bacteria multiply in large numbers [20].

The Centers for Disease Control (CDC) estimates that in the USA, 2.8 million people are infected with antibioticresistant fungi or bacteria every year, and over 35,000 people die [21]. Antibiotic-resistant bacteria can infect people of all ages, making antibiotic resistance one of the most crucial public health concerns. Several advances in medicine depend on their capability to fight infections through the use of antibiotics, such as organ transplants, cancer therapy, joint replacements, and treatment of chronic diseases, including asthma, diabetes, and rheumatoid arthritis [21]. Further emergence of microbial resistance is expected due to the damage to the environment caused by anthropogenic activities (such as glacier melting caused by global warming), which may unlock ancient microbes and cause direct infection or interact with nonpathogenic microbes, which may be transformed into deadly antibiotic resistant pathogens [22]. Our previous review concluded that the world should be prepared in the forms of pedagogy, vaccine, and antibiotics development against the emergence of new pathogens and antibiotics resistance war [22]. Now, the question is, how can we prepare for such crisis? One possible solution is to isolate natural antibiotics from the pristine environments, including glaciers, hydrothermal vents, deepsea trenches, etc., where microbes produce unique metabolites to adapt to the hostile conditions. These metabolites can be used as antimicrobial and biomedical agents. One 
such pristine environment is the cave ecosystems. This review focuses on the need for effective and reliable drugs and describes the cave ecosystems that were once homes and hospitals for prehistoric humans, and now they are an important potential source of biomedical and antimicrobial agents. In addition, how to use modern molecular techniques to explore the cave microbial world is discussed.

\section{Cave ecosystems}

A cave is a completely dark, natural underground hollow space with constant temperature, high humidity, low pressure, low oxygen concentration, and a nutrients-limited ecosystem [23]. Caves are present worldwide in different geographical conditions (Fig. 1). Caves are formed by various geological processes, such as chemical reactions of different compounds, rock dissolution, cave rock weathering, glacier melting, and corrosion of rocks by water, tectonic forces, atmospheric influences, microorganisms, and also by anthropogenic excavation [24]. Caves are divided into three zones based on light penetration: entrance zone, twilight zone, and dark zone (Fig. 2). The entrance zone is similar to the outside environment, with a length of approximately $5 \mathrm{~m}$, receiving full sunlight where photosynthetic life (plants) exists, and the temperature varies with the outer environment. In the twilight zone, there is less light penetration with a length of 10-20 m, where photosynthetic activities halt, and no plants survive in this zone. The temperature remains constant but occasionally fluctuates with the aboveground weather. The dark zone is completely dark with constant temperature throughout the year.

There are many types of cave locations, such as aquatic caves, terrestrial caves (e.g., ice caves, lava caves), and sea caves [23, 25, 26]. Most reported caves are composed of limestone, gypsum, and dolomite rocks [27]. In addition to calcite, other interesting minerals reported in caves are aragonite, similar to calcium carbonate $\left(\mathrm{CaCO}_{3}\right)$, but not as common as $\mathrm{CaCO}_{3}$, and mainly found in intricate needles called anthodites [28]. Selenite was also reported in some

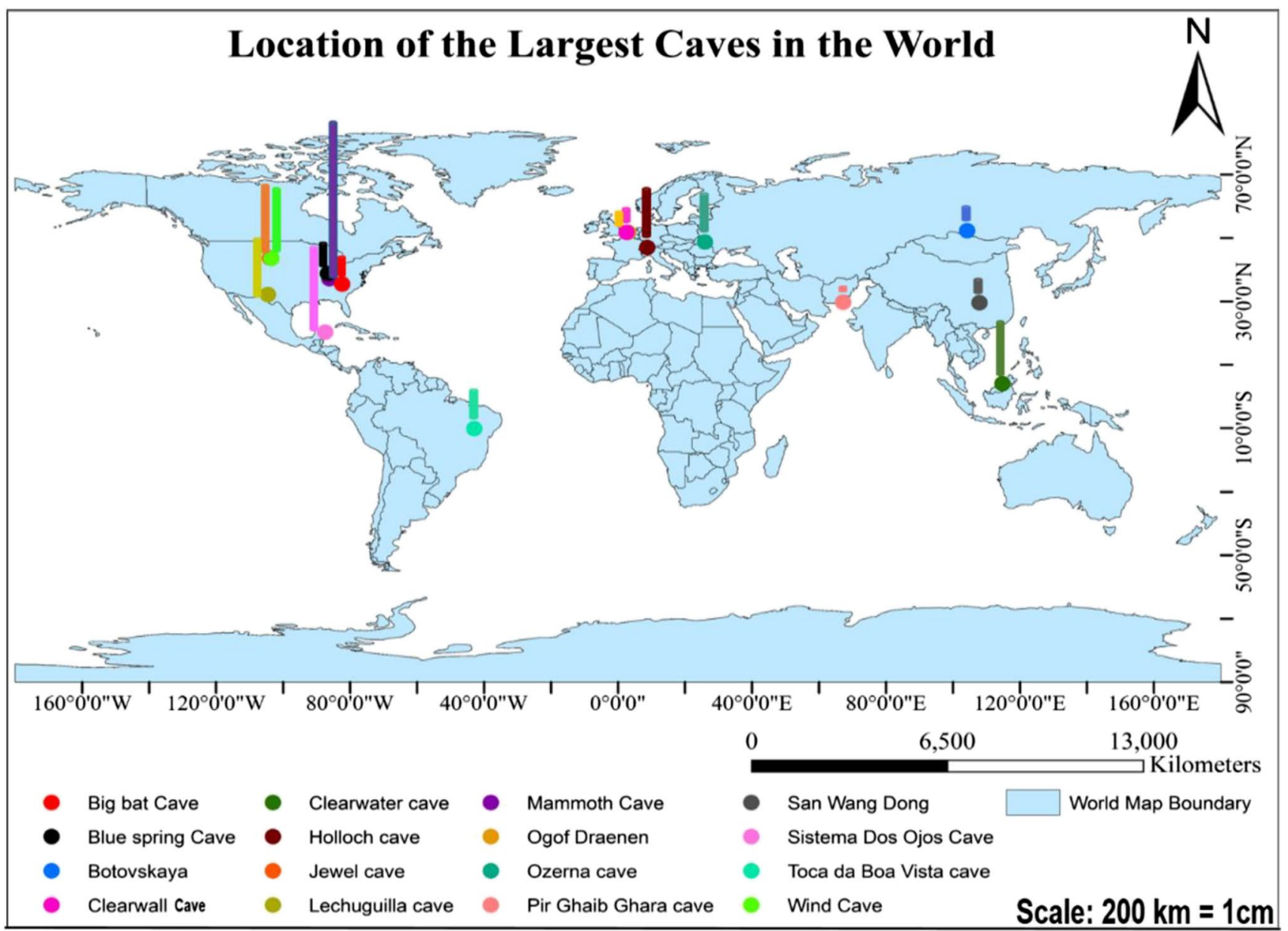

Fig. 1 Cave environments reported worldwide in different geographical locations 


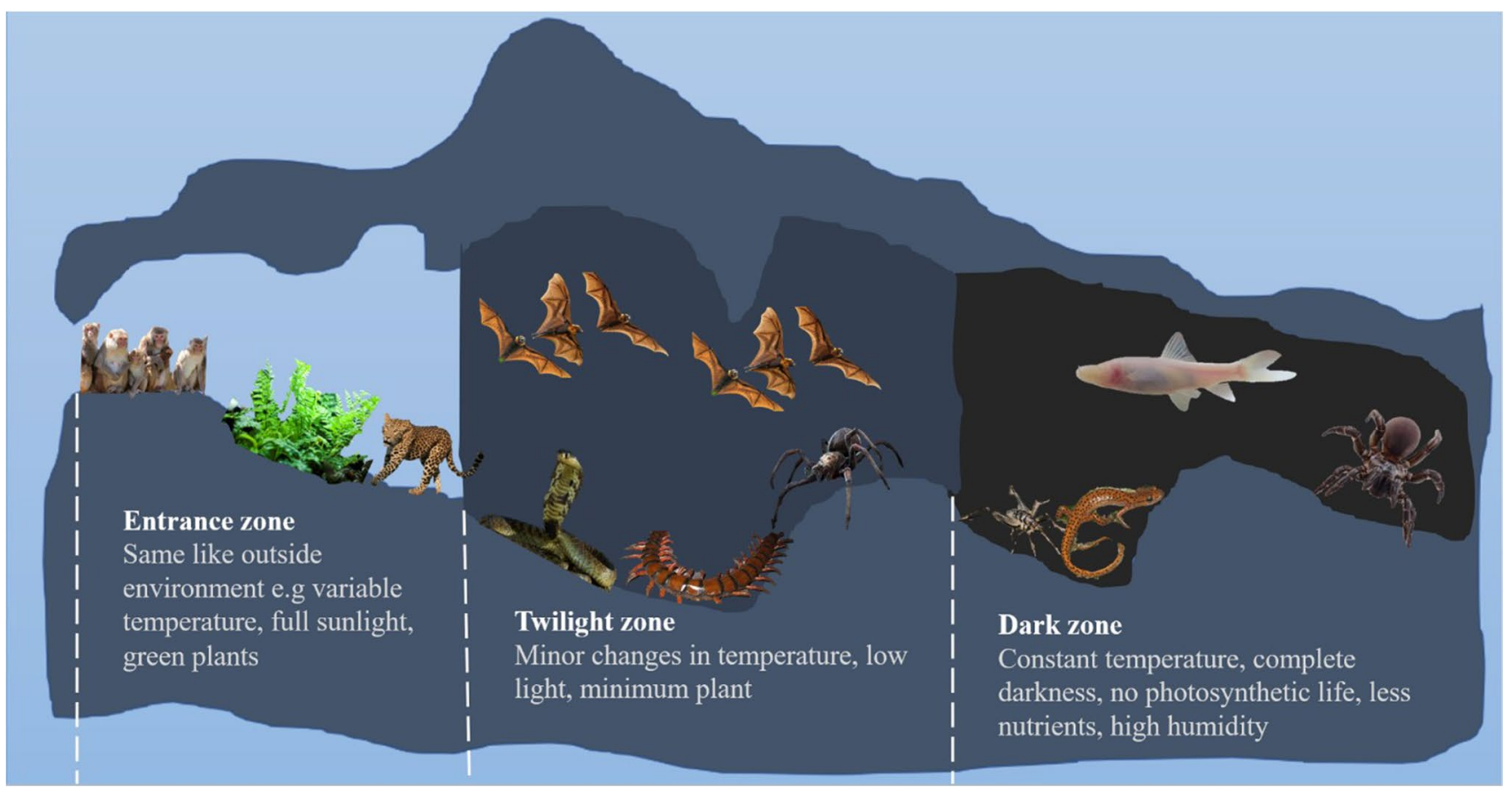

Fig. 2 Illustration of the different zones in the cave ecosystem

caves in small concentrations [27]. Sodium and magnesium sulfates are also found in some cave systems [29]. Other minerals, including limonite, goethite, calcium nitrites, barite, celestite endellite, and attapulgite, are also found in cave environments [30]. The largest cave in the world is Mammoth Cave, which is located in Kentucky, USA. It is a limestone cave that encompasses approximately 80 square miles and is 365 miles long (explored to date, the endpoint remains undiscovered). For thousands of years, water seeping from the limestone ceiling has formed thousands of stalactites [31]. Animals living in the caves have undeveloped eyes, long antennae, and a lack of pigment [32].

\section{The association between humans and caves}

Since the prehistoric era, caves have played a key role in benefiting humankind. The connection between humans and caves is as old as human history itself. Caves are considered significant natural resources because of their unique attraction, history, and their role in a healthy environment. Caves play an important role in groundwater flow and are home to threatened and endangered animals. Some caves also preserve sculptures of prehistoric animals and artifacts of early humans. Pre-historic people used caves for different purposes, such as shelters, old sanctuaries, sources of water, clay, and other materials. There is some evidence that the first home of humankind was a cave. Parts of Australopithecines (man-like creatures) have been found in cave deposits in South Africa [33], and the first evidence of early Neanderthal humankind was found in a cave in Germany [34]. The Cro-Magnon people created their extraordinary paintings on the cave walls in France and Spain, where they took sanctuary during the ice age more than 10,000 years ago [35]. Cave ecosystems are a mystery. Researchers need to explore the hidden and fragile world inside caves. In the mountains of central Mexico, archaeologists excavated a cave with strong evidence that people lived in this area more than 30,000 years ago [36]. Recently, the remaining Neanderthal-like skulls and jaws parts were found inside a cave in Italy [37] (reported by BBC, 11 May 2021, https:// www.bbc.com/news/science-environment-52614870). The Neanderthals lived about 40,000 years ago. From their remains, it is suggested that these peoples lived in the cave about 50,000 - 68,000 years ago. The Paleolithic paintings on the cave walls provide clear evidence of anthropogenic activities inside caves.

The Ajanta caves (consisting of 29 caves) in India were built in the second century BCE [38]. They are one of the world Heritage sites of the United Nations Educational, Scientific and Cultural Organization (UNESCO). These caves were used for religious activities and have long been regarded as a sacred site in India. The Mesolithic period witnessed the first use and modification of the early caves. Many rock-cut Hindu and Buddhist sculptures and paintings were found in these caves, which are masterpieces of Buddhist religious art [39]. Caves were also used as wine and beer cellars because of their constant temperature. Due 


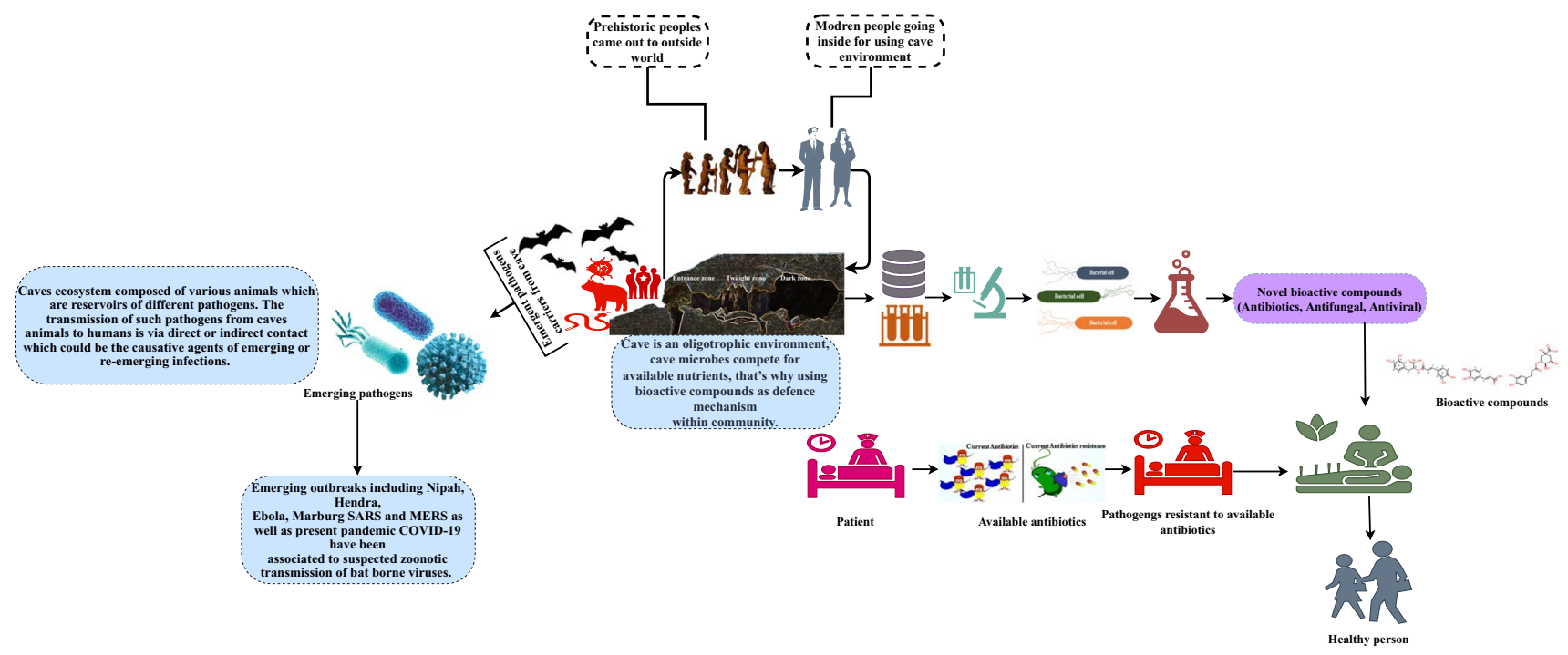

Fig. 3 Cavernicoles as a potential source of antimicrobial and biomedical agents

to the high humidity and constant temperature throughout the year, people used caves as a hospital for the treatment of respiratory diseases [33]. In the past, caves were also used to celebrate rituals of passage, bury wealth, Paleolithic paintings, historical landmarks, and hidden treasures hunting. After the evolution of civilization, people forgot the importance of caves [35]. Based on the above evidence, it can be suggested that early people emerged from the depths of the earth. In addition, there is a possibility that an entire civilization lives beneath the ground in the fourth corner region. Caves are another world beneath this world, which can be called a subterranean world.

\section{Medical perspectives of caves}

The cave environment is completely different from the outside environment. The microenvironments and air composition in caves depend on geology, depth of the cave, annual mean temperature, ventilation, and cave water temperature. The air in the cave is characterized by high humidity, cleanliness, condensed vapors, constant temperature, low salt contents, rich in antibiotics (produced by mold fungi spores), and high self-purification potential [23]. In addition, the air in the cave is free from germs, dust particles, and allergens, which makes it the best place to treat patients with respiratory tract infection, a practice called speleotherapy. The air in caves also contains anti-inflammatory calcium, magnesium, and iodine ions that are most beneficial to patients with respiratory disease [33]. Speleotherapy is a more efficient and effective treatment than the sanatorium of mountains, complemented with various other therapies [40]. Historically, many caves in Hungary have been used to treat different respiratory diseases. Owing to $97 \%$ humidity, $12.6{ }^{\circ} \mathrm{C}$ temperature, presence of $\mathrm{Ca}$ ion (an anti-inflammatory agent) in the air of Abaliget Cave, the clinical symptoms of patients with respiratory diseases (e.g., asthma, allergies, and silicosis) were relieved. Similarly, Aggteleki Cave, Tapolca basin Cave (Hospital cave), Szemlohegyi Cave, and Black Hall Cave have been used to treat various respiratory diseases, including bronchitis, asthma, allergies, and other respiratory problems [41]. From the study of Paleolithic cave painting, anthropologists believe that due to the sterile conditions of the cave, early people used trepanning to treat patients with migraines, mental disorders, and epileptic seizures [42, 43]. In the current COVID-19 pandemic, caves could be used as an isolation ward. It is also possible that prehistoric people may have used sulfidic caves for skincare. From the medical illustrations on the cave walls, it is reasonable to believe that caves not only played a pivotal role in teaching but also played a vital role in the development of modern surgery. For the above reasons, caves should be considered as a school of science and medicine.

\section{Discovery of drugs from cave ecosystems}

It is believed that microorganisms from pristine environments, which have not been explored or have relatively negligible anthropogenic activities, are likely to be novel microbes that producing novel and unique biological compounds. The unique characteristics of cave environments, such as complete darkness, high humidity, constant low temperature, and lack of nutrients, may promote the production of antimicrobial (antibiotics, antifungal, and antiviral) and anticancer compounds (Fig. 3). 


\section{a) Antibiotics production}

Multi-drug-resistant pathogens pose a serious threat to world health [44]. Most new antibiotics have been discovered by identifying bioactive compounds from traditional drugs or accidental discovery. As an important source of bioactive compounds, microbes play a crucial role in the production of antibiotics. Due to the existence of unexplored microbial ecosystems, extreme pristine environments (especially cave environments) have attracted the attention of researchers. The lack of nutrients in the cave ecosystems stimulates competition among microbes and causes them to develop survival strategies, such as the secretion of metabolites (antibiotics and enzymes). However, caverns could be considered a peerless ecosystem for the discovery of novel antibiotics (Table 1).

Owing to the high demand for the discovery of novel drugs, cave ecosystems have been used for more than 30 years and remains under observation [45]. Globally, different caves have been investigated for potential bioactive compounds. It is suggested that novel strains could produce new antimicrobial compounds, and some bacteria have a higher potential to produce special bioactive metabolites than other bacteria $[46,47]$. Streptomyces belonging to Actinobacteria is known to produce potentially bioactive molecules containing antimetabolites, antibiotics, and anticancer agents. Approximately $45 \%$ of known bioactive compounds are secreted by Actinobacteria, of which $85 \%$ are derived from the Streptomyces genus [48]. The occurrence of the Streptomyces genus was documented in many caves, including the Mungkorn Tong Cave in Thailand [49], Karst Cave in Turkey [50], Kashmir Cave in Pakistan [28], Kotumsar Cave in India [51], Miroc Mountain Cave in Serbia [52], Helmcken Falls Cave in Canada [53, 54], a limestone cave in China [55], Bolshaya Cave in Russia [45], Azorean and Canadian volcanic caves [56], Chaabe Cave in Algeria [57], Iron Curtain Cave in Chilliwack, Canada [58], Parsik Cave in Turkey [59], and Scarisoara ice cave in Romania [60]. Other genera of Actinobacteria (Arthrobacter, Nocardia, Saccharothrix, Lentzea, Micrococcus, Nonomuraea, Spirillospora, Micromonospora, Microbacterium, Cryobacterium, and Lysinibacter) were also reported in various cave environments [56, 58, 62 -66]. In addition to Actinobacteria, other bacterial phyla such as Firmicutes, Bacteroidetes, Cyanobacteria, and Proteobacteria existing in cave environments $[61,62]$ have shown the potential to produce bioactive metabolites and have become the research hotspot for geo-microbiologists.

Although the production of antimicrobial compounds from cavernicoles is a hot research topic, only a few bioactive compounds have been reported in this pristine environment. In most cases, the chemical properties of bioactive compounds secreted by specific bacteria are unknown. The identified bioactive compounds include bacteriocin such as peptides of the Bacillus licheniformis strain [28, 63], undecylprodigiosin of Streptomyces sp. [52], cervimycins of Streptomyces tendae [64], xiakemycin of Streptomyces sp. [65], lipids of Toxopsis calypsus and Phormidium melanochroun [62], a mixture of antibiotics of Streptomyces sp., Bacillus sp. and Bacillaceae [45], a mixture of polyene and nonpolyene metabolites of Streptomyces sp. and Penicillium sp. [57], huanglongmycin of Streptomyces sp. [65], chaxalactin B of Streptomyces sp. [13], diazepinomicin of Streptomyces sp. [58], lanthipeptides, polymyxin B, paenicidin B, fusaricidin, tridecaptin, and colistin A of Paenibacillus [66, 67].

The discovery of novel bioactive compounds emphasizes the significance of caves and other pristine environments in the development of novel antibiotics. Bacteria have spent trillions of years acquiring chemical weapons to inhibit the growth of other bacteria [68]. Cave ecosystems have become favorite environments for bioprospecting of microbes with active compounds. Such pristine ecosystems are often linked with traditional medicine. Pre-historic people used moon-milk (white exudates covering the surface of caves) to treat many diseases, which has potential against multiple bacteria and fungi $[49,69]$. Such a new and unstudied ecosystem could help to identify new bioactive compounds to combat antibiotic resistant pathogens and perhaps provide urgently needed structural microbial diversity for the production of novel antibiotics.

\section{b) Antifungal compounds production}

The treatment of incursive fungal diseases remains a challenge due to the toxicity of antifungal drugs, limited routes of administration, restriction, and resistance of antifungal drugs. Fungal infections are the most difficult diseases to manage in humankind, with approximately 1700 million people suffering from fungal infections globally [70, 71]. Incursive fungal infections advert to systemic infections in which fungal strains infiltrated and developed themselves in tissues, resulting in life-threatening infections [72]. At present, few antifungal drugs are available on the market, and many of them could not treat drug-resistant fungi. Fungi and bacteria show various interactions in different ecosystems, from cozy existence to depredation [73]. The first antifungal drug was discovered in a bacterial strain mediator of such interaction, and the bacterial population continues to be the best source of antifungal drugs. Studying the ecological interactions between fungi and bacteria may help understand the evolution of bioactive compounds. 
Globally, various caverns have been investigated for novel antimicrobial compounds [45]. It is suggested that there should be novel bacterial and fungal strains with different interactions in the cave environments, which could be a significant source of novel antifungal compounds. Currently, $90 \%$ of antimicrobial compounds are derived from bacteria belonging to the phylum Actinobacteria, particularly the Streptomycetaceae family [74, 75]. In cave environments, Actinobacteria are the dominant group of bacteria, and such an ecosystem provides a prosperous reservoir for the discovery of novel bacteria $[76,77]$. Despite the dominant group of bacteria in cave ecosystem, the cultured-based study is limited [78]. Streptomyces sp. from five different caves in Mexico and the USA has been reported to inhibit the growth of Pseudogymnoascus destructans fungus, which is the causative agent of white-nose syndrome in bats, killing more than 600,000 bats in only 7 years [78]. Other examples of antifungal compounds from cave environments have also been documented. Micromonospora, Streptomyces, Dactylosporangium, and Streptosporangium were reported in different caves in Korea, and they have activities against Colletotrichum gloeosporioides, Alternaria solani, Fusarium oxysporum sp. Magnaporthe grisea, lycopersici, Rhizoctonia solani, and Phytophthora capsici fungi [79]. Nimaichand et al. [80] reported that Janibacter and Streptomyces from a limestone cave in Manipur, India, showed bioactive and biocontrol activities against Candida, $F$. oxysporum, $R$. solani, Curvularia oryzae, Helminthosporum oryzae, R. pryzae-sativae, and Pyricularia oryzae fungus. Recently, Belyagoubi et al. [57] isolated Streptomyces sp. from the Chaaba cave, Algeria, to produce nonpolyenic bioactive compounds against Candida albicans.

Cave animals are reservoirs of bacterial populations. Bacteria are symbiotic with cave animals (beetles, salamanders, isopods, cave crickets, millipedes and insects, and other arthropods). Bacteria protect cave animals from fungal attacks by killing pathogenic fungi through secretion of bioactive antifungal metabolites [81]. Insects and arthropods produce various antifungal compounds, such as specialist peptides, cuticular excretions, venoms, and hemolymph. Some arthropods use additional antifungal molecules derived from mutualistic bacteria [81]. Various arthropods and insects have mutualistic associations with microbes, indicating that natural selection has favored them in such cave ecosystems over those who depend upon endogenic production of antifungal compounds. Fukuda et al. [81] studied the symbiotic relationship between arthropod and bacteria (Pseudonocardia $\mathrm{sp}$.) and found that bacteria provide chemical weapons against the pathogenic fungi, and in return, they are fed by the host. Otani et al. [82], identi- fied seven different bacterial phyla in Macrotermitinae gut, in which the Bacillus sp. strain was dominant and could produce secondary metabolites (polyene polyketide and bacillaene) to inhibit the growth of Trichoderma, Pseudoxylaria, Coriolopsis, Fusarium, and Umbelopsis. Therefore, microbes from caves with complex environments have a well-known association with cave insects. These cave microbes might directly associate with other cave life (cave animals) such as bats. Therefore, this pattern of association could disclose possible association with outside life, especially humans.

\section{c) Anticancer drugs production}

Cancer is one of the most deadly diseases, where abnormal cells grow and have the ability to spread to other parts of the body. In 2019, approximately 108.5 million people suffered from this life-threatening disease [83]. Cancer is caused by different carcinogens, such as genetic mutations, chemicals, tobacco, infections, radiation, and pollution [84, 85]. A major challenge for scientists is to discover effective anticancer compounds to treat this life-threatening disease. At present, there are few drugs for cancer treatment [44]. Microbes from pristine environments such as caves are regarded as an auspicious source of anticancer drugs. Biospeleologists believe that the combination of cavernicoles (oligotrophic) and metals in caves intervenes with DNA. The huge competition between microbes in cave ecosystems favors the synthesis of bioactive compounds that inhibit the growth of competitors with possible action on cancer cells. Some Actinobacteria isolated from cave ecosystems have been screened for the production of bioactive compounds against cancer. Spirillospora albida, Nonomuraea monospora, and Nonomurea roseola reported from the Phanangkhoi cave, Thailand, showed anticancer activity against lung cancer cells [86]. Similarly, Dos-Santos et al. [87] analyzed extracts of Bacillus subitilis isolated from Pedra da Cachoeira cave Brazil, and the $\mathrm{IC}_{50}$ values indicated that these microbes are promising to produce anticancer compounds. These reports provided evidence that cave microbes have the potential for novel anticancer compound production.

\section{d) Antiviral drugs production}

Today, the world is in chaos due to the COVID-19 pandemic. According to several researchers, more viral outbreaks are likely to occur in the near future [22]. Therefore, we need to be prepared in terms of developing antiviral drugs and vaccines. Viral infection is a worldwide health threat. In the past 50 years, many antiviral drugs have been developed and successfully fought against some viruses. However, some viral infections, such as the influenza epidemic, HCV, HIV, and COVID19 , are still spreading globally. Due to the high variability of the viral genomes, the virus quickly exhibits resist- 
Table 1 Antibiotic-producing bacteria reported from cave ecosystems

\begin{tabular}{|c|c|c|c|c|}
\hline No & Antibiotics & Strain name & Cave & Reference \\
\hline 1 & Bacteriocin & Bacillus licheniformis & Kashmir Cave, Pakistan & 30 \\
\hline 2 & Undecylprodigiosin & Streptomyces sp. & Miroc Cave, Serbia & 54 \\
\hline 3 & Cervimycins & Streptomyces tendae & Grotta dei Cervi Cave, Italy & 69 \\
\hline 4 & Xiakemycin & Streptomyces sp & Karst soil, China & 69 \\
\hline 5 & Mix antibiotics & $\begin{array}{l}\text { Streptomyces sp., } \\
\text { Bacillus sp., and } \\
\text { Bacillaceae }\end{array}$ & Bolshaya Oreshnaya Cave, Siberia & 47 \\
\hline 6 & $\begin{array}{l}\text { Polyene and nonpol- } \\
\text { yene metabolites }\end{array}$ & $\begin{array}{l}\text { Streptomyces sp. and } \\
\text { Penicillium sp }\end{array}$ & Chaabe Cave, Algeria & 59 \\
\hline 7 & Huanglongmycin & Streptomyces sp. & Xiangxi Cave, China & 70 \\
\hline 8 & Chaxalactin B & Streptomyces sp. & Chaxa Lagoon, Chile & 13 \\
\hline 9 & Diazepinomicin & Streptomyces sp. & Iron Curtain Cave, Chilliwack, Canada & 60 \\
\hline 10 & Lanthipeptides & Paenibacillus & & 71 \\
\hline 11 & Polymyxin B & Paenibacillus sp. & Krubera-Voronja Cave, Georgia & 72 \\
\hline 12 & Hypogeamicins & Nonomuraea specus & Hardin's Cave, Tennessee, USA & 111 \\
\hline 13 & Paenicidin B & Paenibacillus sp. & Krubera-Voronja Cave, Georgia & 72 \\
\hline 14 & Cyclodysidin D & Streptomyces sp. & Bolshaya Oreshnaya Cave, Siberia & 47 \\
\hline 15 & Fusaricidin & Paenibacillus sp. & Krubera-Voronja Cave, Georgia & 72 \\
\hline 16 & Chaxalactin B & Streptomyces sp. & Bolshaya Oreshnaya Cave, Siberia & 47 \\
\hline 17 & Tridecaptin & Paenibacillus sp. & Krubera-Voronja Cave, Georgia & 72 \\
\hline 18 & Stylissazole B & Streptomyces sp. & Bolshaya Oreshnaya Cave, Siberia & 47 \\
\hline 19 & Colistin A & Paenibacillus sp. & Krubera-Voronja Cave, Georgia & 72 \\
\hline 20 & Gyrophoric acid & Streptomyces sp. & Bolshaya Oreshnaya Cave, Siberia & 47 \\
\hline
\end{tabular}

ance to antiviral drugs. COVID-19 is the best example of the emergence of multiple variants in a short time [5]. Viral infections, including from the Ebola virus, Zika virus, MERS CoV, severe acute respiratory syndrome coronavirus, and COVID-19 have caused great damage to public health. However, there remain no effective vaccines or drugs against these viruses on the market. In this regard, scientists are searching for novel microbes to produce bioactive antiviral compounds to treat these lethal infections. Unique microbes with the potential to produce new bioactive compounds live in cave ecosystems.

In cave soil, the load of the viral population is negligible, and only $0.2 \%$ of sequences were of the virus in 960,000 total sequences [88]. The study of virus diversity in cave environments remains a hot research topic. Viruses have only been incidentally reported from cave ecosystems. However, no reports on viral diversity in cave soil, water, or sediments have been conducted. Cave animals, such as rodents, bats, reptiles, birds, arthropods, amphibians, and others are the reservoirs of viruses in cave ecosystems. Bats are incredibly unique virus reservoirs. Bats are unique mammals, with immunological, ecological, and behavioral ascribes that make them different from other mammals. Bats have an exceptional number of species, composing $20 \%$ of all other mammalian species, and are the only true flying mammals [89]. Bats are relatively long-lived mammals because of their body's size, and temperate species often undergo hibernation or torpor [90]. There exist different theories about why bats are unique reservoirs of viruses and seldom experience viral infections.

Bats have to deal with the physiological stress of flight, which increases metabolic rates and subsequent enhancement in reactive oxygen species [91]. Recent studies reported that bats' innate immune system may allow them to coexist with viruses, maintaining very small frictions of viremia or keeping viruses in a dormant state [92, 93]. Cave ecosystems are the best hideout for bats where they hang upside down the whole day from cave ceiling defecating and sleeping. Bats' excrements, such as urine and feces, could be composed of some pathogenic viruses. Mendenhall et al. [94] reported vertebrates' pathogenic virus families from urine and feces of bats, including Flaviviridae, Adenoviridae, Papillomaviridae, Reoviridae, Parvoviridae, Paramyxoviridae, Polyomaviridae, and Picornaviridae. Similarly, the genomic study of cave bats serum in China and Singapore detected evidence of coronaviruses, astroviruses, and filoviruses [95, 96]. In some regions such as West Africa, meat of different animals, including monkeys, rats, and bats, eaten by humans has contained 
various viral infections and the serum of those individuals tested positive for the Ebola virus, rabies, and coronavirus [97].

Bats are believed to be the reservoirs of various coronaviruses, including SARS-CoV and SARS-CoV-2, the causative agent of COVID-19. Nonetheless, the evolution of coronaviruses remains a question. All coronaviruses that infect human beings are of zoonotic or animal origin, especially from the bat host [98]. These viruses spill out from cave bats to humans either directly via contact with carrier bats or indirectly through intermediate hosts such as wildlife or domestic animals that have been contaminated by saliva, blood, feces, or urine of infected bats. A few major viral emerging outbreaks, including Nipah, Hendra, Ebola, Marburg SARS, and MERS as well as the present COVID-19 pandemic have been associated with suspected zoonotic transmission of bat-borne viruses. It has also been announced that bats were the probable source of the Zaire strain of the Ebola virus, which was the causative agent of Ebola in 2013-2016 in West Africa [99]. The recent COVID-19 pandemic has led to 216.2 million cases and more than 4.499 million deaths (WHO COVID-19 Status Report, 2021). During the transmission of the COVID-19 virus from bats to humans, the intermediate host remains unclear, but it is believed to have an ancestral origin in bats with the closest similarity to bats' coronavirus [100, 101]. Paenibacillus sp. and Bacillus sp. were reported from the cave ecosystem and produced different lipopeptides such as octapeptins, polymyxins, iturins, fengycins, polypeptins, fusaricidins, tridecaptins, kurstakins, and surfactins, which showed bioactivity against different viruses [102].

Latinne et al. [98] estimated that cave bats harbor about 15,000 coronaviruses and only a few hundred are currently identified. Direct or indirect contact with bats poses a huge risk of emerging new life-threatening infections. To prevent such deadly high-risk viruses, educating people in those areas with a high prevalence of such lethal pathogenic viruses is mandatory. People should plug holes in their houses to prevent bats from entering. Boil milk of all animals before drinking to kill off the viruses and avoid eating fruits bats might have bitten. Cave and bat hunters must wear proper sampling suits to avoid body contact with bats and their excrement. In addition to the spreading of the emergence and reemergence of pathogens from cave bats, the serum of bats contains antibodies that were produced to fight off these viruses and could act as the basis for developing novel drugs and vaccines or plasma treatment against new emerging pathogens.

Cave microbial populations may also comprise a massive viral community that needs to be evaluated, which could potentially help scientists solve the issues about cavernicoles interactions and population dynamics. Cave viruses could also be helpful as therapeutic agents because of their capable lytic characteristics. Cave environments are associated with infection outbreaks and chances of further outbreaks are expected. Therefore, caves are hotspots for researchers to study the nature of their genome structure, possible mode of infection, mode of transmission, and design protection against more outbreaks in the form of vaccines or any other therapeutic agents or precautionary measures.

\section{Future prospects and conclusions}

Caves are pristine and oligotrophic ecosystems that may contain novel microbes that could produce new metabolites. In addition, animals in caves are reservoirs of different pathogens that are crucial to be explored to better understand their pathogenicity. The emergence of novel pathogens and existing antibiotic-resistance pathogens are threats to global health. Therefore, the need for new drugs is increasing daily. The new screening methods of metagenomics, high throughput screening, and metabolomics should be used to seek novel bioactive compounds. The advancement of next-generation sequencing and the accumulation of high-quality whole genome data provide powerful tools and valuable information to support the search for novel bioactive metabolites for drug development. However, under laboratory conditions, gene clusters responsible for bioactive compounds are usually not expressed. Therefore, activating these silent gene clusters is a challenge. Metagenomics has enabled the advancement of the knowledge base of cavernicoles diversity in cave ecosystems and opened doors to identify new bacterial strains. The integration of metagenomics and current advanced techniques (such as genome mining, in silico design, genetic engineering, medicinal chemistry, and metabolomics) could help to produce target-specific antimicrobial compounds to solve the problem of antibiotics resistance. Cave microbes could be the headline makers in the sense of bioactive compound production, biomineralization, polycyclic aromatic hydrocarbons degradation, enzyme production, and various other areas.

This review presents the relationship between prehistoric humans and caves. Caves were the possible home of ancient humans. Humans have now abandoned these sites; however, a unique microbial world still lives in caves, and other animals use caves as shelters. In an oligotrophic environment, cave microbes compete within communities by producing bioactive agents. Several studies have reported the synthesis of antimicrobial and other biomedically important metabolites from cave microorganisms. Therefore, antimicrobial 
agents and other metabolites produced by cave microbes could provide relief to the modern-day crisis in the biomedical sector, including the emergence of new pathogens and antibiotic resistance. Cave ecosystems may provide a hotspot to explore antimicrobial compounds by adapting modern molecular techniques.

Authors contributions SZ and WS devised the study, drafted this article, and equally contributed as first authors, MR and SA collected the literature, and $\mathrm{ZH}, \mathrm{HW}$, and $\mathrm{RC}$ revised critically.

Funding Funding for this study was provided by the National Natural Science Foundation of China (32070113) and the Guangdong Science and Technology Department (2019ST023, 2019A1515011139). Wasim Sajjad is supported by a PIFI Fellowship from the Chinese Academy of Sciences (2020PC0052).

\section{Declarations}

Ethical statement This article does not contain any human and animal studies. This review article has not been submitted or published elsewhere in any language (fully or partially).

Consent to participate Not applicable.

Consent to publish Not applicable.

Conflict of interest The authors declare that they have no conflict of interest.

\section{References}

1. Hennessey M, Fischer M, Staples JE (2016) Zika virus spreads to new areas-region of the Americas, May 2015-January 2016. MMWR Morb Mortal Wkly Rep 65:55-58

2. Heymann DL, Chen L, Takemi K, Fidler DP, Tappero JW, Thomas MJ, Kenyon TA et al (2015) Global health security: the wider lessons from the west African Ebola virus disease epidemic. Lancet 385:1884-1901

3. Ramadan N, Shaib H (2019) Middle East respiratory syndrome coronavirus (MERS-CoV): a review. Germs 9:35-42

4. WHO (2018) MERS-CoV global summary and assessment of risk, August 2018 (WHO/MERS/RA/August18). Switzerland, Geneva

5. Stawicki SP, Jeanmonod R, Miller AC, Paladino L, Gaieski DF, Yaffee AQ et al (2020) The 2019-2020 novel coronavirus (severe acute respiratory syndrome coronavirus 2) pandemic: A joint american college of academic international medicine-world academic council of emergency medicine multidisciplinary COVID19 working group consensus paper. J Glob Infect Dis 12:47

6. Law YH (2013) Rare human outbreak of monkey malaria detected in Malaysia. Nature 2018:16

7. Cabanel N, Leclercq A, Chenal-Francisque V, Annajar B, Rajerison M, Bekkhoucha S et al (2013) Plague outbreak in Libya, 2009, unrelated to plague in Algeria. Emerg Infect Dis 19:230

8. Baillie GJ, Galiano M, Agapow P-M, Myers R, Chiam R, Gall A et al (2012) Evolutionary dynamics of local pandemic
H1N1/2009 influenza virus lineages revealed by whole-genome analysis. J Virol 86:11-18

9. Wu Z, Harrich D, Li Z, Hu D, Li D (2021) The unique features of SARS-CoV-2 transmission: comparison with SARS-CoV, MERS-CoV and 2009 H1N1 pandemic influenza virus. Rev Med Virol 31:e2171s

10. Sikka V, Chattu VK, Popli RK, Galwankar SC, Kelkar D, Sawicki SG et al (2016) The emergence of Zika virus as a global health security threat: a review and a consensus statement of the INDUSEM Joint Working Group (JWG). J Glob Infect Dis 8:3

11. Klein EY, Van Boeckel TP, Martinez EM, Pant S, Gandra S, Levin SA et al (2018) Global increase and geographic convergence in antibiotic consumption between 2000 and 2015. Proc Natl Acad Sci 115:E3463-E3470

12. Ventola CL (2015) The antibiotic resistance crisis: part 1: causes and threats. P T 40:277-283

13. Castro JF, Razmilic V, Gomez-Escribano JP, Andrews B, Asenjo J, Bibb M (2018) The 'gifted'actinomycete Streptomyces leeuwenhoekii. Antonie Van Leeuwenhoek 111:1433-1148

14. Singh KS, Sharma R, Reddy PAN, Vonteddu P, Good M, Sundarrajan A et al (2021) IspH inhibitors kill Gram-negative bacteria and mobilize immune clearance. Nature 589:597-602

15. Thornsberry C, Sahm DF, Kelly LJ, Critchley IA, Jones ME, Evangelista AT et al (2002) Regional trends in antimicrobial resistance among clinical isolates of Streptococcus pneumoniae, Haemophilus influenzae, and Moraxella catarrhalis in the United States: results from the TRUST Surveillance Program, 1999-2000. Clin Infect Dis 34:S4-16

16. Palumbi SR (2001) Humans as the world's greatest evolutionary force. Science 293:1786-1790

17. Von Döhren H (2004) Antibiotics: actions, origins, resistance, by C. Walsh. 2003. Washington, DC: ASM Press. 345 pp. $\$ 99.95$ (hardcover). Protein Sci A Publ Protein Soc 13:3059

18. Majhi S (2021) Applications of Yamaguchi method to esterification and macrolactonization in total synthesis of bioactive natural products. Chem Select 6:4178-4206

19. Mobarki N, Almerabi B, Hattan A (2019) Antibiotic resistance crisis. Int J Med Dev Ctries 40:561-564

20. Walsh C (2003) Where will new antibiotics come from? Nat Rev Microbiol 1:65-70

21. Piña B, Bayona JM, Christou A, Fatta-Kassinos D, Guillon E, Lambropoulou D et al (2020) On the contribution of reclaimed wastewater irrigation to the potential exposure of humans to antibiotics, antibiotic resistant bacteria and antibiotic resistance genes-NEREUS COST Action ES1403 position paper. J Environ Chem Eng 8:102131

22. Sajjad W, Rafiq M, Din G, Hasan F, Iqbal A, Zada S et al (2020) Resurrection of inactive microbes and resistome present in the natural frozen world: reality or myth? Sci Total Environ 735: 139275

23. Burcham J (2009) Learning about caves; how caves are formed. Journey into amazing caves. Project Underground. Retrieved Sept 2009

24. Engel AS, Stern LA, Bennett PC (2004) Microbial contributions to cave formation: New insights into sulfuric acid speleogenesis. Geol 32:369-372

25. Ford DC (2006) Karst geomorphology, caves and cave deposits: a review of North American contributions during the past half century. Spec Pap Soc Am 404:1

26. Mylroie JE, Mylroie JR (2013) Caves and karst of the Bahama Islands. Coastal Karst Landforms, Springer, Dordrecht pp $147-176$

27. Li X, Cui X, He D, Liao J, Hu C (2018) Evaluation of the Heshang Cave stalagmite calcium isotope composition as a 
paleohydrologic proxy by comparison with the instrumental precipitation record. Sci Rep 8:1-7

28. Zada S, Naseem AA, Lee S-J, Rafiq M, Khan I, Shah AA et al (2016) Geochemical and mineralogical analysis of Kashmir Cave (SMAST), Buner, Pakistan, and isolation and characterization of bacteria having antibacterial activity. J Cave Karst Stud 78:96-109

29. Levy DB, Amrhein C (2011) Geochemical evolution of hypersaline cave pools, Guadalupe Mountains, New Mexico. Chem Geol 290:60-66

30. Bögli A (1980) Karst hydrology and physical speleology. Springer, Heidelberg

31. Algeo K (2004) Mammoth Cave and the making of place. Southeast Geogr 44:27-47

32. Pipan T, Deharveng L, Culver DC (2020) Hotspots of subterranean biodiversity. Oxford University Press, Oxford

33. Pellini JR (2015) Coming to senses: topics in sensory archaeology. Cambridge Scholars, Cambridge

34. Hofreiter M, Münzel S, Conard N, Pollack J, Slatkin M, Weiss $\mathrm{G}$ et al (2007) Sudden replacement of cave bear mitrochondrial DNA in the Late Pleistocene. Curr Biol 17:R122-R123

35. Blum HP (2011) The psychological birth of art: a psychoanalytic approach to pre-historic cave art. Int Forum Psychoanal 20:196-204

36. Ardelean CF, Becerra-Valdivia L, Pedersen MW, Schwenninger J-L, Oviatt CG, Macías-Quintero JI et al (2020) Evidence of human occupation in Mexico around the Last Glacial Maximum. Nature 584:87-92

37. Devièse T, Abrams G, Hajdinjak M, Pirson S, De Groote I, Di Modica K et al (2021) Reevaluating the timing of Neanderthal disappearance in Northwest Europe. Proc Natl Acad Sci 118:e2022466118

38. Singh M, Arbad BR (2015) Characterization of 4th-5th century A.D. earthen plaster support layers of Ajanta mural paintings. Constr Build Mater 82:142-154

39. Artioli D, Capanna F, Giovagnoli A, Ioele M, Marcone A, Mariottini M et al (2008) Mural paintings of Ajanta Caves, part II: Non destructive investigations and microanalysis on execution technique and state of conservation. 9th Int. Conf. NDT Art, Jerusalem Isr. 25-30 May 2008.

40. Mętel S, Kostrzon M, Adamiak J, Gattner H, Kościelecka D, Sosulska A et al (2020) The influence of speleotherapy combined with pulmonary rehabilitation on functional fitness in older adults - preliminary report. Ther Adv Respir Dis 14:1753466620926952-1753466620926952

41. Albert G, Virág M, Erôss A (2015) Karst porosity estimations from archive cave surveys-studies in the Buda Thermal Karst System (Hungary). Int J Speleol 44:3

42. Netter FH (1956) (1956) Medical illustration; its history and present day practice. J Int Coll Surg 26:505-513

43. Clottes J (2016) What is Paleolithic Art?: cave paintings and the dawn of human creativity. University of Chicago Press, Chicago

44. Shanmuganathan R, Lewis-Oscar F, Shanmugam S, Thajuddin N, Alharbi SA, Alharbi NS, Brindhadevi K, Pugazhendhi A (2020) Core/shell nanoparticles: synthesis, investigation of antimicrobial potential and photocatalytic degradation of Rhodamine. B J Photochem Photobiol B Biol 202:111729

45. Axenov-Gibanov DV, Voytsekhovskaya IV, Tokovenko BT, Protasov ES, Gamaiunov SV, Rebets YV et al (2016) Actinobacteria isolated from an underground lake and moonmilk speleothem from the biggest conglomeratic karstic cave in Siberia as sources of novel biologically active compounds. PLoS One 11:e0149216

46. Ma HK, Liu MM, Li SY, Wu Q, Chen JC, Chen GQ (2013) Application of polyhydroxyalkanoate (PHA) synthesis regulatory protein PhaR as a bio-surfactant and bactericidal agent. J Biotechnol 166:34-41
47. Monciardini P, Iorio M, Maffioli S, Sosio M, Donadio S (2014) Discovering new bioactive molecules from microbial sources. Microb Biotechnol 7:209-220

48. Goodfellow M, Fiedler H-P (2010) A guide to successful bioprospecting: informed by actinobacterial systematics. Antonie Van Leeuwenhoek 98:119-142

49. Rangseekaew P, Pathom-aree W (2019) Cave Actinobacteria as producers of bioactive metabolites. Front Microbiol 10:387

50. Yücel S, Yamaç M (2010) Selection of Streptomyces isolates from Turkish karstic caves against antibiotic resistant microorganisms. Pak J Pharm Sci 23:1-6

51. Yogita R, Jayant B, Vibhuti R (2012) Potentiality test in antimicrobial activity and antibiotic sensitivity of subterranean Streptomyces strains isolated from Kotumsar cave of India. Int J Biol Chem 6:53-60

52. Stankovic N, Radulovic V, Petkovic M, Vuckovic I, Jadranin M, Vasiljevic B et al (2012) Streptomyces sp. JS520 produces exceptionally high quantities of undecylprodigiosin with antibacterial, antioxidative, and UV-protective properties. Appl Microbiol Biotechnol 96:1217-1231

53. Sadoway T, Rule D, Watson K, Moote P, Soliman LC, Azad N et al (2013) Cure from the cave: volcanic cave actinomycetes and their potential in drug discovery. Int J Speleol 42:5

54. Rule D, Cheeptham N (2013) The effects of UV light on the antimicrobial activities of cave actinomycetes. Int J Speleol 42:7

55. Jiang Z, Guo L, Chen C, Liu S, Zhang L, Dai S et al (2015) Xiakemycin A, a novel pyranonaphthoquinone antibiotic, produced by the Streptomyces sp. CC8-201 from the soil of a karst cave. J Antibiot (Tokyo) 68:771-774

56. Gabriel C, Dapkevicius M de L, Miller A, Charlop-Powers Z, Brady S, Mason C et al (2017) Biotechnological potential of Actinobacteria from Canadian and Azorean volcanic caves. Appl Microbiol Biotechnol 101843-857

57. Belyagoubi L, Belyagoubi-Benhammou N, Jurado V, Dupont J, Lacoste S, Djebbah F et al (2018) Antimicrobial activities of culturable microorganisms (actinomycetes and fungi) isolated from Chaabe Cave. Algeria Int J Speleol 47:8

58. Gosse JT, Ghosh S, Sproule A, Overy D, Cheeptham N, Boddy CN (2019) Whole genome sequencing and metabolomic study of cave Streptomyces isolates ICC1 and ICC4. Front Microbiol 10:1020

59. Çandiroğlu B, Doğruöz Güngör N. The biotechnological potentials of bacteria isolated from Parsik Cave, Turkey. Johnson Matthey Technol Rev 64:396-406

60. Paun VI, Lavin P, Chifiriuc MC, Purcarea C (2021) First report on antibiotic resistance and antimicrobial activity of bacterial isolates from 13,000-year old cave ice core. Sci Rep 11:1-15

61. Tomova I, Lazarkevich I, Tomova A, Kambourova M, VasilevaTonkova E (2013) Diversity and biosynthetic potential of culturable aerobic heterotrophic bacteria isolated from Magura Cave. Bulgaria Int J Speleol 42:8

62. Lamprinou V, Tryfinopoulou K, Velonakis EN, Vatopoulos A, Antonopoulou S, Fragopoulou E et al (2015) Cave cyanobacteria showing antibacterial activity. Int J Speleol 44:1

63. Gálvez A, Maqueda M, Martínez-Bueno M, Lebbadi M, Valdivia E (1993) Isolation and physico-chemical characterization of an antifungal and antibacterial peptide produced by Bacillus licheniformis A12. Appl Microbiol Biotechnol 39:438-442

64. Herold K, Gollmick FA, Groth I, Roth M, Menzel KD, Möllmann U et al (2005) Cervimycin A-D: a polyketide glycoside complex from a cave bacterium can defeat vancomycin resistance. Chem - A Eur J 11:5523-5530

65. Jiang L, Pu H, Xiang J, Su M, Yan X, Yang D et al (2018) Huanglongmycin A-C, cytotoxic polyketides biosynthesized by a putative type II polyketide synthase from Streptomyces sp. CB09001. Front Chem 6:254 
66. Baindara P, Nallabelli N, Korpole S (2020) Whole genome mining reveals a diverse repertoire of lanthionine synthetases and lanthipeptides among the genus Paenibacillus. J Appl Microbiol 128:473-490

67. Lebedeva J, Jukneviciute G, Čepaitė R, Vickackaite V, Pranckute R, Kuisiene N (2021) Genome mining and characterization of biosynthetic gene clusters in two cave strains of Paenibacillus sp. Front Microbiol 11:3433

68. Riedel S (2004) Biological warfare and bioterrorism: a historical review. Proc (Bayl Univ Med Cent) 17:400-406

69. Maciejewska M, Adam D, Martinet L, Naômé A, Całusińska M, Delfosse P et al (2016) A phenotypic and genotypic analysis of the antimicrobial potential of cultivable Streptomyces isolated from cave moonmilk deposits. Front Microbiol 7:1455

70. Denning DW, Bromley MJ (2015) Infectious disease. How to bolster the antifungal pipeline. Science 347:1414-1416

71. Brown GD, Denning DW, Gow NAR, Levitz SM, Netea MG, White TC (2012) Hidden killers: human fungal infections. Sci Transl Med 4:165rv13

72. Ramana KV, Kandi SP, Sharada CH, Rao R, Mani R, Rao SD (2013) Invasive fungal infections: a comprehensive review. Am J Infect Dis Microbiol 1:64-69

73. Jia S-L, Chi Z, Liu G-L, Hu Z, Chi Z-M (2020) Fungi in mangrove ecosystems and their potential applications. Crit Rev Biotechnol 40:852-864

74. Wohlleben W, Mast Y, Stegmann E, Ziemert N (2016) Antibiotic drug discovery. Microb. Biotechnol 9:541-548

75. Schrempf H (2001) Recognition and degradation of chitin by streptomycetes. Antonie Van Leeuwenhoek 79:285-289

76. Ko KS, Kim Y, Seong CN, Lee SD (2015) Rhodococcus antrifimi sp. nov., isolated from dried bat dung of a cave. Int J Syst Evol Microbiol 65:4043-4048

77. Gutierrez-Patricio S, Jurado V, Laiz L, Sáiz-Jiménez C (2014) Two new species of bacteria isolated from white colonizations in Andalusian caves. Proc Sci Technol Cult Heritage Sevilla, Spain, 24-27 June, pp 281-288.

78. Hamm PS, Caimi NA, Northup DE, Valdez EW, Buecher DC, Dunlap CA et al (2017) Western bats as a reservoir of novel streptomyces species with antifungal activity. Appl Environ Microbiol 83:e03057-e3116

79. Kim BS, Lee JY, Hwang BK (1998) Diversity of actinomycetes antagonistic to plant pathogenic fungi in cave and sea-mud soils of Korea. J Microbiol 36:86-92

80. Nimaichand S, Devi AM, Tamreihao K, Ningthoujam DS, Li W-J (2015) Actinobacterial diversity in limestone deposit sites in Hundung, Manipur (India) and their antimicrobial activities. Front Microbiol 6:413

81. Fukuda TTH, Helfrich EJN, Mevers E, Melo WGP, Van Arnam EB, Andes DR et al (2021) Specialized metabolites reveal evolutionary history and geographic dispersion of a multilateral symbiosis. ACS Cent Sci 7:292-299

82. Otani S, Mikaelyan A, Nobre T, Hansen LH, Koné NA, Sørensen SJ et al (2014) Identifying the core microbial community in the gut of fungus-growing termites. Mol Ecol 23:4631-4644

83. Bergers G, Fendt S-M (2021) The metabolism of cancer cells during metastasis. Nat Rev Cancer 21:162-180

84. Zhang X, Liu X, Luo J, Xiao W, Ye X, Chen M et al (2016) Notch3 inhibits epithelial-mesenchymal transition by activating Kibra-mediated Hippo/YAP signaling in breast cancer epithelial cells. Oncogenesis 5:e269

85. Islami F, Goding Sauer A, Miller KD, Siegel RL, Fedewa SA, Jacobs EJ et al (2018) Proportion and number of cancer cases and deaths attributable to potentially modifiable risk factors in the United States. CA Cancer J Clin 68:31-54
86. Nakaew N, Pathom-Aree W, Lumyong S (2009) First record of the isolation, identification and biological activity of a new strain of Spirillospora albida from Thai cave soil. Actinomycetologica 23:1-7

87. Dos Santos RS, Albino UB, Paludo KS, Silva SYS, Oliveira MN, Santos DDA et al (2021) Extract of bacterial strain isolated from cave in the eastern Amazon induces selective cytotoxicity on tumor line of murine melanoma. Sci Plena 17:1-9

88. Kumaresan D, Wischer D, Stephenson J, Hillebrand-Voiculescu A, Murrell JC (2014) Microbiology of Movile Cave-A Chemolithoautotrophic Ecosystem. Geomicrobiol J 31:186-193

89. Calisher CH, Childs JE, Field HE, Holmes KV, Schountz T (2006) Bats: important reservoir hosts of emerging viruses. Clin Microbiol Rev 19:531-545

90. Kunz TH, Fenton MB (2005) Bat ecology. University of Chicago Press, Chicago

91. Cooke MS, Evans MD, Dizdaroglu M, Lunec J (2003) Oxidative DNA damage: mechanisms, mutation, and disease. FASEB J 17:1195-1214

92. Ahn M, Cui J, Irving AT, Wang L-F (2016) Unique loss of the PYHIN gene family in bats amongst mammals: implications for inflammasome sensing. Sci Rep 6:1-7

93. Xie J, Li Y, Shen X, Goh G, Zhu Y, Cui J et al (2018) Dampened STING-dependent interferon activation in bats. Cell Host Microbe 23:297-301

94. Mendenhall IH, Wen DLH, Jayakumar J, Gunalan V, Wang L, Mauer-Stroh S et al (2019) Diversity and evolution of viral pathogen community in cave nectar bats (Eonycteris spelaea). Viruses 11:250

95. Mendenhall IH, Borthwick S, Neves ES, Low D, Linster M, Liang B et al (2017) Identification of a lineage D betacoronavirus in cave nectar bats (Eonycteris spelaea) in Singapore and an overview of lineage D reservoir ecology in SE Asian bats. Transbound Emerg Dis 64:1790-1800

96. Laing ED, Mendenhall IH, Linster M, Low DHW, Chen Y, Yan L et al (2018) Serologic evidence of fruit bat exposure to filoviruses, Singapore, 2011-2016. Emerg Infect Dis 24:114-117

97. Akem ES, Pemunta NV (2020) The bat meat chain and perceptions of the risk of contracting Ebola in the Mount Cameroon region. BMC Public Health 20:593

98. Latinne A, Hu B, Olival KJ, Zhu G, Zhang L, Li H et al (2020) Origin and cross-species transmission of bat coronaviruses in China. Nat Commun 11:4235

99. Dalmon A, Diévart V, Thomasson M, Fouque R, Vaissière BE, Guilbaud L et al (2021) Possible spillover of pathogens between bee communities foraging on the same floral resource. Insects $12: 122$

100. Andersen KG, Rambaut A, Lipkin WI, Holmes EC, Garry RF (2020) The proximal origin of SARS-CoV-2. Nat Med 26:450-452

101. Zhou P, Yang X-L, Wang X-G, Hu B, Zhang L, Zhang W et al (2020) A pneumonia outbreak associated with a new coronavirus of probable bat origin. Nature 579:270-273

102. Jastaniah SD, Amasha RH, Alanbari AH (2019) Isolation and identification of some antimicrobial producing bacteria from caves in Summan plateau, Saudi Arabia. https://eli.kau.edu.sa/ Show_Res.aspx? Site_ID=306\&LNG=EN\&RN=73129

Publisher's note Springer Nature remains neutral with regard to jurisdictional claims in published maps and institutional affiliations. 